\title{
Tourists' Expectation And Perception Towards Environmental Issue Management For Green Tourism Of Khao Yai National Park
}

Aurathai Lertwannawit, Ph.D., Suan Dusit Rajabhat University, Thailand Jirawat Anuwichanont, Ph.D., Suan Dusit Rajabhat University, Thailand

\begin{abstract}
This paper presents the results of a study conducted to evaluate tourists' perceptions of environmental issue management in Khao Yai National Park, where has been inscribed as a natural UNESCO World Heritage Site under the name Dong Phaya Yen-KhaoYai Forest Complex since 2005. The information could assist in addressing tourists' perception in order to improve the management of the site for sustainable green tourism. The current study was carried out in 4 sites located in the complex. The sample size for this research is 654 tourists. The study analyzes six issues of environmental issue management, which are pollution, facilities, safety, regulation enforcement, eco-tourism activities, and stakeholder collaboration. Each dimension was rated both in term of expectation and perception. Positive gaps are found between the scores of perception and expectation of environmental issue management, implying that environmental issue management in the complex is more effective than tourists' expect it to be.
\end{abstract}

Keywords: Environmental Issue Management; Green Tourism; Khao Yai National Park

\section{INTRODUCTION}

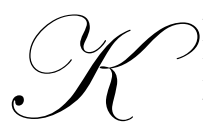

hao Yai National Park is the first national park in Thailand. The park is situated in the Sankambeng Mountain Range, the southern prolongation of the Dong Phaya Yen Mountains, at the southwestern boundary of the Khorat Plateau. This park lies largely in Nakhon Ratchasima Province (Kho-rat), but also includes parts of Saraburi, Prachinburi and Nakhon Nayok provinces. The area occupies 2,168.75 square kilometers, which make it second largest national park in Thailand, including evergreen forests and grasslands. Its altitude ranges from 400 to 1000 meters above sea level. Khao Yai national park consists of a variety of landscapes ranging from plateau landscapes in some parts to tropical rain forests. The natural conditions give rise to diverse natural habitats for complex species of flora and fauna. The areas have abundant plant and animal species, many of which are rare and endangered. There are 3,000 species of plants, 5,000 species of insects, 340 species of birds like red jungle fowl and green peafowl and 67 species of mammals, including Asiatic black bears, Asian elephants, gaur, tigers, gibbons, Indian sambar deer, crab-eating macaque, Indian muntjac, dholes, and wild pigs. Its waterfalls include the 150 metre Heo Narok and Heo Suwat, made famous from the film The Beach. Namtok Sarika is popular with the Thais (Protected Area Regional Office 1, 2011). In 2005, Khao Yai National Park and neighboring areas, including Pang Sida national park, Tab Larn national park, Ta Phraya national park and Dong Yai wildlife sanctuary, were inscribed as IUCN Category II (National Park) on UNESCO World Heritage Site under the name Dong Phaya Yen-KhaoYai Forest Complex (World Heritage Convention, 2011). The complex situates in Saraburi, Nakhon Nayok, Nakhon Rachisima, Prachinburi, Srakaew and Burirum, with the total area of 615,500 ha.

In addition to biodiversity reserved area, the complex has also been utilized as a green tourism or eco-tourism site under enforcement of national park act B.E. 2504 (or A.D. 1961) with additional amendment in 
B.E.2532 (or A.D.1989). The development of the area to serve tourists can degrade the forest resource through pollution from tourist invasions. The National Park Committee faces challenges because future benefits from inscription as a UNESCO World Heritage Site can influence and threaten biodiversity and sustainable living in the complex (Albers \& Robinson, 2007), which, eventually, could give reason to retract its world heritage award. Thus, this research is initiated under the strategic issues management for sustainable green tourism of the world heritage master plan. The aim of this research is to study tourists' expectations and perceptions of environmental issue management in the park. The data will help the national park committee to manage the complex, create additional values, and sustain development. The research objectives are, firstly, to identify tourists' expectations and perceptions of environmental issues management, which comprises six aspects: pollution, facilities, safety, regulation enforcement, eco-tourism activities, and stakeholder collaboration. Secondly, the comparison between tourists' perceptions and expectations identifies the existence of a gap in tourists' perception. The results should help stakeholders in selecting priority issues to be managed and additional control required. Figure 1 illustrates the research model.

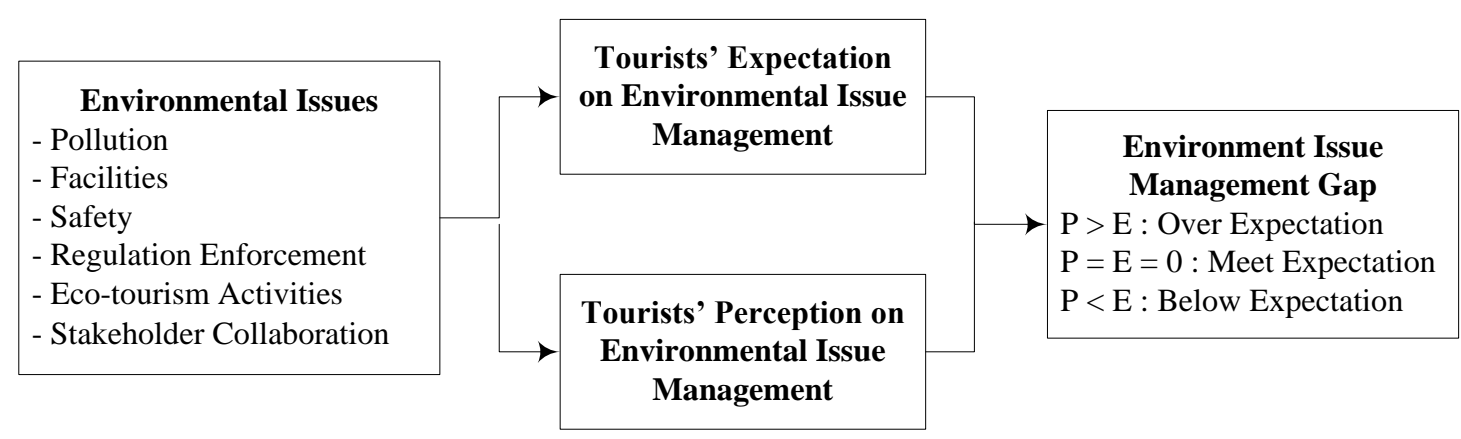

Figure 1 Tourists' Expectation and Perception towards Environmental Issue Management Research Model

\section{LITERATURE REVIEW}

According to the research model in figure 1, the literature review section divides into two parts, environmental issue management and green tourism.

\section{Environmental Issue Management}

Issue management is the discipline and process of management by prioritizing and proactively addressing policy and reputation issues that can affect an organization's success. Issue management is the responsibility of the entire organization. The issue management framework involves four main functions, which are 1) gathering and monitoring information, 2) analyzing the information and classifying the issue, 3) sorting and prioritizing the issue, and 4) developing an action or implementation plan (Heath \& Palenchar, 2009). Environmental issue management has become an important element of resource management over recent decades. The process to be used in environmental issue management should involve stakeholders and potential users and the consideration of social, economic, ecological, and bio-physical factors should be part of the strategy (Argent, Grayson, \& Ewing, 1999). In national restricted area like national parks, environment is critical to the choice of tourists to visit the national park (Kim, Borges, \& Chon, 2006). Consequently, for sustaining utilizing the complex, planners should consider how complex use values may change over time (Albers \& Robinson, 2007). Environmental issue management has a major role as a management tool in identifying environmental issues in the areas (Hvenegaard \& Dearden, 1998; Meyer \& Geary, 1993; Molina-Azorín, Claver-Cortés, López-Gamero, \& Tarí, 2009)

\section{Green Tourism}

Green tourism or Eco-tourism is a strategic tourism management tool for utilizing natural sites to generate income and also main sustainability of biodiversity (Hvenegaard \& Dearden, 1998). It postulates many unique challenges and opportunities for protected area and tourism stakeholders and challenges stakeholders to deliver on 
the conservation potential of ecotourism activities (Wallace and Pierce 1996) and to accurately assess the current and potential size of the ecotourism market (Durst 1994). The ultimate goal is to develop a model that allows tourism without destroying the environment. The participation of all stakeholders - local people, government agencies, private entities, and tourists - in preserving the environment is necessary to ensure success. The designation of the complex as a UNESCO world heritage site can generate revenue and draw world attention to their natural importance through tourism. However, the growth of tourism raises a number of concerns over threats to wildlife and biodiversity as a result of tourists' intrusion. The development of sustainable tourism would allow for tourism without sacrificing the attractions upon which it subsists, and enable future generations the opportunities to benefit from their heritage (Drost, 1996).

\section{RESEARCH METHODOLOGY}

This study uses quantitative methodology. A self-administered survey questionnaire was used to gather data from the tourists at Khao Yai National Park.

\section{Sample Design and Data Collection}

The current study was carried out in Khao Yai National Park and Thai tourists were the target population. Domestic tourism was selected because there is marginal significance for international visitors (Peleggi, 1996). Since a sampling frame was not available, probabilistic sampling techniques could not be used. Sample selection was a result of combining the convenience method and the interviewers' judgment. The questionnaires were administered personally to the respondents. Data were gathered during from February 2011 to April 2011. Five sites were chosen as survey points, in order to capture the socio-demographic diversity of the population under study, from Khao Yai, Pang Sida, Tab Larn, Dong Yai, and Ta Phraya, where most of the tourists were discharged.

\section{Measures}

A self-administered survey questionnaire was used to gather data from the tourists at Khao Yai National Park. The structured questionnaire consisted of three parts. The first part attempted to identify the respondents' socio-demographic characteristics. The second part identifies the respondents' tourism behavior. The last part measured respondents' perception of environmental issue management All latent constructs for environmental issue management expectation and perception were measured on a five-point Likert scale ranging from "strongly agree" (5) to "strongly disagree" (1). Exploratory factor analysis (EFA) was conducted in conjunction with all of the multidimensional constructs. The descriptions of each construct are described below.

Pollution. The natural park committee is responsible in managing all pollution occurring in the site. The output results in term of good quality environment in the area. This construct measure in term of tourists expectation and perception of good quality environment in term of waste, water and hygienic, noise, air quality and electricity availability in the area.

Facilities. The development of facilities to serve tourists is a dilemma for natural resource management. The human invasion should not degrade the forest resources and biodiversity, but the facilities provided should provide comfort for the tourists. Consequently, the interaction of the nature and human invasion should be balanced. The constructs measure tourists' expectation and perception in term of road condition in the park, landscape architecture in the tourism area, and food and beverage services provided to serve the tourists.

Safety. For green tourism, safety issues are important factors that all tourists have to consider. Safety is measured in terms of safety during tourist activities, safety from wildlife, anti-thief safety, and essential safety recommendations at the site.

Regulation Enforcement. The forest complex is managed under the terms of the National Park Act. The construct is measured by tourists' expectation and perception of the enforcement of regulations, incluing a limit to the number of tourists allowed to access the park, recreation area management, wildlife and forest preservative practice, complex edge alignment, restricted forest area, and forest cutting prohibitions. 
Eco-tourism Activities. Eco-tourism activities available in the complex objectively contribute wildlife and biodiversity knowledge to the tourists. The constructs measure tourists' expectation and perception of agency management of supporting learning processes, including trekking, communication tools, tourism centers, supportive activities, and officers' services.

Stakeholder Collaboration. Sustainable development cannot be successful without the collaboration of all stakeholders including local communities, government officers, private entities, tourists, and scholars. The construct measures tourists' expectation and perception of border management, tourist participation, and community involvement.

Table 1 summarizes descriptive statistics and reliability constructs for this research.

Table 1 Environmental Issue Management Constructs Descriptive Statistics and Reliability Result

\begin{tabular}{|c|c|c|c|c|c|c|c|c|c|c|c|c|c|}
\hline \multirow{3}{*}{$\begin{array}{c}\text { Environment Issues } \\
\text { Management }\end{array}$} & \multirow{3}{*}{$\begin{array}{c}\text { No. } \\
\text { of } \\
\text { Items }\end{array}$} & \multicolumn{2}{|c|}{ Mean } & \multicolumn{2}{|c|}{ S.D. } & \multicolumn{4}{|c|}{ Factor loadings } & \multirow{2}{*}{\multicolumn{2}{|c|}{$\begin{array}{c}\text { Cronbach } \\
\text { Alpha }\end{array}$}} & \multirow{2}{*}{\multicolumn{2}{|c|}{ Squared Multiple Correlation }} \\
\hline & & \multirow{2}{*}{$\mathbf{E}$} & \multirow{2}{*}{$\mathbf{P}$} & \multirow{2}{*}{$\mathbf{E}$} & \multirow{2}{*}{$\mathbf{P}$} & \multicolumn{2}{|c|}{ Expectation } & \multicolumn{2}{|c|}{ Perception } & & & & \\
\hline & & & & & & Lowest & Highest & Lowest & Highest & $\mathbf{E}$ & $\mathbf{P}$ & $\mathbf{E}$ & $\mathbf{P}$ \\
\hline \multicolumn{14}{|l|}{ Pollution } \\
\hline - Waste & 4 & 3.252 & 3.395 & 0.799 & 0.849 & 0.719 & 0.789 & 0.774 & 0.804 & 0.913 & 0.911 & $0.598-0.703$ & $0.642-0.703$ \\
\hline - Water and Hygienic & 6 & 3.192 & 3.286 & 0.860 & 0.868 & 0.690 & 0.826 & 0.628 & 0.854 & 0.938 & 0.925 & 0.736-0.809 & $0.682-0.795$ \\
\hline - Noise & 3 & 3.356 & 3.565 & 0.851 & 1.018 & .0674 & 0.083 & 0.774 & 0.873 & 0.811 & 0.875 & $0.391-0.524$ & $0.567-0.603$ \\
\hline - Air Quality & 3 & 3.609 & 3.905 & 0.854 & 0.797 & 0.646 & 0.878 & 0.692 & 0.859 & 0.851 & 0.803 & $0.438-0.610$ & $0.364-0.540$ \\
\hline - Electricity Availability & 3 & 3.168 & 3.335 & 0.891 & 0.877 & 0.764 & 0.844 & 0.777 & 0.862 & 0.910 & 0.892 & $0.603-0.729$ & $0.521-0.717$ \\
\hline \multicolumn{14}{|l|}{ Facilities } \\
\hline - Road Condition & 3 & 3.325 & 3.502 & 0.822 & 0.811 & 0.769 & 0.806 & 0.784 & 0.827 & 0.908 & 0.900 & $0.623-0.732$ & $0.583-0.717$ \\
\hline - Landscape Architecture & 9 & 3.465 & 3.708 & 0.717 & 0.678 & 0.687 & 0.838 & 0.667 & 0.802 & 0.949 & 0.933 & $0.691-0.795$ & $0.568-0.735$ \\
\hline - Food \& Beverage Service & 5 & 2.992 & 3.038 & 0.884 & 0.914 & 0.798 & 0.848 & 0.782 & 0.875 & 0.928 & 0.919 & $0.605-0.782$ & $0.615-0.742$ \\
\hline Safety & 4 & 3.422 & 3.652 & 0.790 & 0.705 & 0.880 & 0.923 & 0.837 & 0.905 & 0.922 & 0.897 & $0.624-0.747$ & $0.519-0.666$ \\
\hline Regulation Enforcement & 6 & 3.403 & 3.593 & 0.783 & 0.769 & 0.834 & 0.910 & 0.800 & 0.896 & 0.943 & 0.928 & $0.621-0.809$ & $0.581-0.766$ \\
\hline Eco-tourism Activities & 7 & 3.336 & 3.422 & 0.746 & 0.805 & 0.832 & 0.895 & 0.817 & 0.896 & 0.945 & 0.939 & $0.641-0.751$ & $0.600-0.749$ \\
\hline Stakeholder Collaboration & 3 & 3.342 & 3.468 & 0.813 & 0.827 & 0.912 & 0.929 & 0.888 & 0.918 & 0.907 & 0.886 & $0.645-0.698$ & $0.568-0.652$ \\
\hline
\end{tabular}

Remark: E=Expectation and $\mathrm{P}=$ Perception

\section{RESULTS}

The results are divided into two parts. The first part is about tourists' demographics and their tourism behavior. The second part includes the empirical test of the tourists' expectations and perceptions of Environmental Issue Management for Green Tourism in Khao Yai National Park. Paired sample t-tests were employed on each environmental issue management dimension to tests if there were any significant differences among them.

\section{Tourists' demographics and their tourism behavior}

654 tourists participated in this research. The majority of subjects were female $51.6 \%$, age between $25-34$ years $31.9 \%$, single $52.3 \%$, and graduate level $48.6 \%$, details shown in Table 2. The most important reasons in travelling in the sites, rating on a 7 point scale with 7 as the most important, are purified air $(\overline{\mathrm{x}}=5.67)$, natural abundance and nature's beauty $(\overline{\mathrm{x}}=5.44)$, UNESCO world heritage site $(\overline{\mathrm{x}}=5.36)$, and rich variety of wildlife $(\overline{\mathrm{x}}$ $=5.32$ ). $87.8 \%$ of tourists were travelling by themselves, $51.1 \%$ were first time visitors, and $80.7 \%$ traveled by private car. Popular tourism activities at the site include trekking (74.4\%), wildlife biodiversity $(48.4 \%)$, and visiting the waterfall $(19.3 \%)$. The majority of tourists travel with an additional 5 travel companions, and the average expenditure is around 65 USD ( 1 USD $=32$ Thai Baht). 
Table 2 Tourists' Demographics at Khao Yai National Park $(n=654)$

\begin{tabular}{|l|l|c|}
\hline Variables & Categories & Percent \\
\hline Gender & Male & 48.4 \\
\cline { 2 - 3 } & Female & 51.6 \\
\hline Age (Years) & Less than 15 & 2.8 \\
\cline { 2 - 3 } & $15-24$ & 24.4 \\
\cline { 2 - 3 } & $25-35$ & 31.9 \\
\cline { 2 - 3 } & $35-44$ & 22.7 \\
\cline { 2 - 3 } & $45-54$ & 11.4 \\
\cline { 2 - 3 } & $55-64$ & 6.4 \\
\cline { 2 - 3 } & Older than 64 & 0.4 \\
\hline Marital Status & Single & 52.3 \\
\cline { 2 - 3 } & Married/Live Together & 43.5 \\
\cline { 2 - 3 } & Divorce/Separated & 4.2 \\
\hline Education & College & 40.6 \\
\cline { 2 - 3 } & Graduate & 48.6 \\
\cline { 2 - 3 } & Post Graduate & 10.8 \\
\hline
\end{tabular}

\section{Empirical Testing of Tourists' Expectation and Perception toward Environmental Issue Management}

Tourists had higher perceptions of actual performance than their expectations had prepared them for in all six areas of environmental issues management. The two most favorable performance areas are air quality $\left(\Delta \overline{\mathrm{X}}_{\mathrm{P}-\mathrm{E}}=\right.$ 0.296), landscape architecture $\left(\Delta \overline{\mathrm{X}}_{\mathrm{P}-\mathrm{E}}=0.243\right)$, and noise $\left(\Delta \overline{\mathrm{X}}_{\mathrm{P}-\mathrm{E}}=0.209\right)$. Table 3 presents the mean scores of environmental issues management in term of tourists' expectation, perception, and gap. The mean difference between perception and expectation are all positive value and significantly different at $\mathrm{p}$ value less than 0.05 for water and hygienic and eco-tourism activities, $\mathrm{p}$ value less than 0.01 for stakeholder collaboration, and $\mathrm{p}$ value less than 0.001 for waste, noise, air quality, electricity availability, road condition, landscape architecture, safety, and regulation enforcement. The only exception is in food \& beverage service, which shows no significant difference. Air quality records the highest mean values on both perception $(\overline{\mathrm{x}}=3.905)$ and expectation $(\overline{\mathrm{x}}=3.609)$. This is followed by safety issues, with a mean for perception of 3.652 and expectation of 3.422 . In contrary, food \& beverage service, eco-tourism activities, and water and hygienic are recognized as the most important issues of environmental issues management in tourists' perspective, because of relatively low mean different between perception and expectation.

Table 3 Environment Issue and Gap between Tourists' Perception and Expectations

\begin{tabular}{|c|c|c|c|c|}
\hline \multirow{2}{*}{ Environment Issues Management } & \multicolumn{2}{|c|}{ Mean } & \multirow{2}{*}{$\begin{array}{c}\text { Gap Mean } \\
(\text { P-E) }\end{array}$} & \multirow{2}{*}{ t-value } \\
\hline & Expection & Perception & & \\
\hline \multicolumn{5}{|l|}{ Pollution } \\
\hline - Waste & 3.252 & 3.395 & 0.143 & $3.501 * * *$ \\
\hline - Water and Hygienic & 3.192 & 3.286 & 0.094 & $2.405 *$ \\
\hline - Noise & 3.356 & 3.565 & 0.209 & $4.930 * * *$ \\
\hline - Air Quality & 3.609 & 3.905 & 0.296 & $7.962 * * *$ \\
\hline - Electricity Avalability & 3.168 & 3.335 & 0.167 & $3.886^{* * *}$ \\
\hline \multicolumn{5}{|l|}{ Facilities } \\
\hline - Road Condition & 3.325 & 3.502 & 0.177 & $4.725 * * *$ \\
\hline - Landscape Architecture & 3.465 & 3.708 & 0.243 & $7.458 * * *$ \\
\hline - Food \& Beverage Service & 2.992 & 3.038 & 0.046 & 0.989 (ns) \\
\hline Safety & 3.422 & 3.652 & 0.230 & $6.729 * * *$ \\
\hline Regulation Enforcement & 3.403 & 3.593 & 0.190 & $5.042 * * *$ \\
\hline Eco-tourism Activities & 3.336 & 3.422 & 0.086 & $2.297 *$ \\
\hline Stakeholder Collaboration & 3.342 & 3.468 & 0.126 & $3.146^{* *}$ \\
\hline
\end{tabular}

Remark: 1) Level of significance for t-test at two-tailed test $* \mathrm{p}<0.05$, $* * \mathrm{p}<0.01$, and $* * * \mathrm{p}<0.001$

2) $\mathrm{E}=$ Expectation and $\mathrm{P}=$ Perception 


\section{CONCLUSIONS AND RECOMMENDATIONS}

Tourists' perceptions of environmental issue management are significantly higher than their expectations. This result implies that tourists are relatively satisfied with national park committee management. However, the performance is relatively lower than tourists' expectation in term of food \& beverage service, eco-tourism activities, water and hygiene, and stakeholder coordination, as the difference between perception and expectation is relatively low. In contrary, tourists are satisfied in air quality, safety, and landscape architecture are the most in order. According to the result, the environmental issues are prioritized in term of requirements for improvement -- food \& beverage service, eco-tourism activities, water and hygiene stakeholder coordination. Even though tourists are satisfied with pollution issues management at the complex, the national park committee should put more effort into these areas in order to sustain the environment in the complex, which is a critical selling point for the tourist marketing of the site.

\section{ACKNOWLEDGEMENTS}

This research is sponsored by the Office of the National Research Council of Thailand and Suan Dusit Rajabhat University (Thailand's national budget for fiscal year 2011) under contract number 542021.

\section{AUTHOR INFORMATION}

Aurathai Lertwannawit, Ph.D., Assistant Professor of Business Administration, Graduate School, Suan Dusit Rajabhat University, Bangkok, Thailand. E-mail: aurathai@gmail.com

Jirawat Anuwichanont, Ph.D., Graduate School, Suan Dusit Rajabhat University, Bangkok, Thailand. E-mail: jirawata@hotmail.com

\section{REFERENCES}

1. Albers, H. J., \& Robinson, E. J. Z. (2007). Spatial-temporal aspects of cost-benefit analysis for park management: An example from Khao Yai National Park, Thailand. Journal of Forest Economics, 13(2-3), 129-150.

2. Argent, R. M., Grayson, R. B., \& Ewing, S. A. (1999). Integrated models for environmental management: Issues of process and design. Environment International, 25(6-7), 693-699.

3. Drost, A. (1996). Developing sustainable tourism for world heritage sites. Annals of Tourism Research, 23(2), 479-484.

4. Durst, P. B. (1994). Planning for ecotourism within the framework of the tropical forests action programme. Tiger Paper (FAO), 21(2), 7-14.

5. Heath, R. L., \& Palenchar, M. J. (2009). Strategic Issues Management: Organizations and Public Policy Challenges (Second Edition ed.). California: Sage Publications.

6. Hvenegaard, G. T., \& Dearden, P. (1998). Ecotourism versus tourism in a Thai national park. Annals of Tourism Research, 25(3), 700-720.

7. Kim, H., Borges, M. C., \& Chon, J. (2006). Impacts of environmental values on tourism motivation: The case of FICA, Brazil. Tourism Management, 27(5), 957-967.

8. Meyer, R. A., \& Geary, T. (1993). Thailand: Challenges....... and opportunities. The Cornell Hotel and Restaurant Administration Quarterly, 34(3), 50-55.

9. Molina-Azorín, J. F., Claver-Cortés, E., López-Gamero, M. D., \& Tarí, J. J. (2009). Green management and financial performance: A literature review. Management Decision, 47(7), 1080-1100.

10. Peleggi, M. (1996). National heritage and global tourism in Thailand. Annals of Tourism Research, 23(2), 432-448.

11. Protected Area Regional Office 1. (2011). Khao Yai National Park, from http://www.dnp.go.th/mfcd3/kaoyai.htm

12. Wallace, G. N., \& Pierce, S. M. (1996). An evaluation of ecotourism in Amazonas, Brazil. Annals of Tourism Research, 23(4), 843-873.

13. World Heritage Convention. (2011). Dong Phayayen-Khao Yai Forest Complex, from http://whc.unesco.org/en/list/590 